\title{
Optimal Conditions for Extraction and Purification of Penicillinase Enzyme
}

\author{
Kambiz Najafi ${ }^{\text {DD }}$, Nahid Haghnazari* iD, Kambiz Davari ${ }^{\text {ID }}$, Fatemeh Keshavarzi* iD
}

Department of Biology, Sanandaj Branch, Islamic Azad University, Sanandaj, Iran

\section{ABSTRACT}

Background and Aim: Penicillinase plays diverse roles, such as inducing drug resistance by hydrolyzing the amide bond of beta-lactam factors, the metabolism of cephalosporin-attached prodrugs, as well as the metabolism of some antibiotics, and renal clearance. The present study aimed to evaluate the optimum conditions for extracting and purifying penicillinase enzyme. The enzyme source was Bacillus licheniformis 6346 obtained from the Iranian Research Organization for Science and Technology.

Materials and Methods: $B$. licheniformis was cultured in a medium containing mineral salts, nitrogen compounds and carbon sources. Following the harvesting and preparation of bacterial suspension, the destruction of the bacterial cell wall and crude cell extraction was completed using a combination of lysozyme and weak ultrasonication. Afterward, enzyme amount was determined utilizing chromatography and electrophoresis. Furthermore, the optimum growth temperature and incubation time were assessed based on the absorbance of samples at $240 \mathrm{~nm}$, enzyme activity, aerification intensity optimization, enzyme production time, and optimum $\mathrm{pH}$.

Results: Approximately $8 \mathrm{~g}$ of cells were retrieved in one liter of culture. The optimum pH was determined as 6.5. The heat stability evaluation of the enzyme at different times revealed that the enzyme was stable for more than $1 \mathrm{~h}$ at $20^{\circ} \mathrm{C}-45^{\circ} \mathrm{C}$, while it is inactivated in $10 \mathrm{~min}$ at $60^{\circ} \mathrm{C}$. Moreover, the best incubation time for this bacterium was obtained as $9 \mathrm{~h}$ at $30^{\circ} \mathrm{C}$. In terms of aerification intensity, the highest enzyme production rate of $2394 \mathrm{U} / \mathrm{mL}$ was achieved in a $250 \mathrm{~mL}$ Erlenmeyer flask with a $50 \mathrm{~mL}$ culture medium at 200 RPM. More aerification led to the inhibitory effect of oxygen and reduced enzyme activity.

Conclusion: Our findings showed that the bacterium $B$. licheniformis 6346 can be used for producing penicillinase enzyme in optimum conditions $\left(30^{\circ} \mathrm{C}, 200 \mathrm{RPM}\right.$, and $\left.\mathrm{pH}: 6.5\right)$.

Keywords: Bacillus licheniformis, Optimum conditions, Penicillinase, Purification

Received: 2021/09/05;

Accepted: 2021/11/17;

Published Online: 2021/12/08

\begin{tabular}{|c|c|}
\hline \multirow{2}{*}{ Corresponding Information: } & $\begin{array}{l}\text { Nahid Haghnazari, Department of Biology, Sanandaj Branch, Islamic Azad University, Sanandaj, Iran, } \\
\text { Email: Nahid.haghnazari2020@gmail.com }\end{array}$ \\
\hline & $\begin{array}{l}\text { Fatemeh Keshavarzi, Department of Biology, Sanandaj Branch, Islamic Azad University, Sanandaj, Iran, } \\
\text { Email: f.keshavarzi@iausdj.ac.ir }\end{array}$ \\
\hline (c) (i) (-) & $\begin{array}{l}\text { Copyright (C) 2021, This is an original open-access article distributed under the terms of the Creative Commons Attribution-noncommercial } 4.0 \text { International License which } \\
\text { permits copy and redistribution of the material just in noncommercial usages with proper citation. }\end{array}$ \\
\hline
\end{tabular}

Use your device to scan and read the article online

Najafi K, Haghnazari N, Davari K, Keshavarzi F. Optimal Conditions for Extraction and Purification of Penicillinase Enzyme. Iran J Med Microbiol. 2021; 15 (6) :684-691

Download citation: $\underline{B i b T e X}$ | $\underline{\text { RIS }|~ E n d N o t e ~| ~ M e d l a r s ~|~ P r o C i t e ~| ~ R e f e r e n c e ~ M a n a g e r ~ \mid ~ R e f W o r k s ~}$ Send citation to: $\Leftrightarrow \underline{\text { Mendeley }} 2$ Zotero $\overline{\text { RefWorks }}$

\section{Introduction}

Penicillinase catalyzes the hydrolysis reaction of the beta-lactam ring of antibiotics. This enzyme is found in all bacteria with the mucopeptide cell wall and is involved in synthesizing cell wall peptidoglycan. In addition to its role in nature, penicillinase contributes to drug resistance mediated by the hydrolysis of the amide bonds of beta-lactams and also to the metabolism of cephalosporins-attached prodrugs. Enzymes with beta-lactamase activity have also been reported in human kidneys and play a role in the metabolism and renal clearance of some antibiotics $(1,2)$.

Penicillinases were first obtained from wild isolates. In recent years, genetic engineering and mutation have resulted in the generation of isolates that could highly produce this enzyme and are widely used $(4,5)$. Penicillinase enzyme is applied for the quantitative and qualitative determination of antibiotics formulation in pharmaceutical industries. It is also 
used for preparing laboratory diagnostic kits, such as immunoassays. Moreover, this enzyme is utilized in clinical laboratories and the food industry for determining the level of penicillinase in the metabolism of prodrugs. In genetic engineering, it is applied for distinct operations, including gene expression regulation.

Studies on penicillinase-producing microorganisms showed that this enzyme is produced by diverse microorganisms, including bacteria, mycobacteria, fungi, and yeasts. Consequently, the enzyme could be obtained from whole bacterial cells, extracellular culture medium, fungi spores, and crude cell extracts (1). B. licheniformis is one of the gram-negative penicillinase-generating microorganisms $(3,5)$. Two penicillinase-inducing isolates (i.e., NCTC 749, 6346) known as $B$. subtilis have been investigated in terms of the secretion and induction of penicillinase (6-8), enzymology (9), immunology (10), and physiology (8).

Advances have been made in the taxonomy of Bacillus genius, along with the primary results of bacteriophage-sensitivity tests and standard biochemical reactions. It could be concluded that isolates 749 and 6346 (11) can be suitably categorized as the variants of $B$. licheniformis mainly based on their ability for gas formation following the anaerobic reduction of nitrates. In addition, since an extensive data have been collected about a wide range of Bacillus cultures, it is clear that none of the strains were initially classified on the basis of biochemical background, as they belong to $B$. subtilis, which were formed more than the actual amount of $\beta$-lactamase of real penicillin with or without induction, and secondly, all strains are classified according to other fields, because they belong to $B$. licheniformis, which are penicillinase-inducible.

All ten isolates of $B$. licheniformis produce the wild type of penicillinase and are categorized in one brand or another particular brand of the previously studied isolates 749 and 6346 according to the enzymological and immunologic characteristics (11). Isolation of penicillinase from isolates 749 and 6346 has partly been performed to determine and understand the supplementary and enzymological differences. It has been indicated by diverse molecules with similar chemical composition and presents a biochemical basis for the interpretation of the results of the intra-isolate conversion, including penicillinase genes (6-11).

Studies on enzyme production by Bacillus demonstrated that some factors, such as organic source, the presence of penicillinase inducer, repressors, temperature, aerification, and culture medium $\mathrm{pH}$, play a role in enzyme production (6). According to the studies performed by Simons in 1978 (12), the membrane-attached penicillinase enzyme is both a superficial membrane protein and an integrated protein, which is attached to the cytoplasmic membrane covalently. To determine the percentage of penicillinase enzyme sites and ascertain a higher percentage of the membrane-attached enzyme, triton $\mathrm{X}-100$ is used for the release and stability of the remaining enzyme $(13,14)$. With this background in mind, the current study aimed to assess the optimum conditions for the extraction and purification of penicillinase enzyme from $B$. licheniformis 6346 obtained from the Iranian Research Organization for Science and Technology.

\section{Material and Methods}

\section{Preparation of Crude Cell Extract}

\section{B. licheniformis Culture}

First, B. licheniformis PTCC 1320 (NCIB6346) in NB or NA storage media was cultured on nutrient agar base medium ( $8 \mathrm{~g}$ neutrinos $+15 \mathrm{~g}$ agar per liter of distilled water) as slurry and was incubated at $34^{\circ} \mathrm{C}$ for $24 \mathrm{~h}$. These cultures were stored at $4{ }^{\circ} \mathrm{C}$ and were used in the production medium when needed. The penicillinase production medium or $\mathrm{CH} / \mathrm{S}$ (4 $\mathrm{g}$ peptone, $4 \mathrm{~g}$ casamino hydrolysate acid, $0.25 \mathrm{~g}$

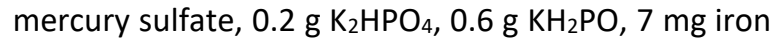
sulfate, $1 \mathrm{mg}$ manganese sulfate, 4 molecules water, $0.1 \mathrm{mg}$ copper sulfate, $4 \mathrm{mg} \mathrm{K}_{2} \mathrm{Cr}_{2} \mathrm{O}_{7}$, and 4 g glucose) was prepared in $1 \mathrm{~L}$ with $\mathrm{pH}$ adjusted to 6.8 using $\mathrm{NaOH}$. Afterward, it was added into a $10 \mathrm{~mL}$ test tube. Glucose was prepared separately and sterilized by autoclave. Next, under completely sterile conditions, a loop full of colonies was cultured in a $10 \mathrm{~mL}$ tube and was incubated at $34^{\circ} \mathrm{C}$ for $24 \mathrm{~h}$. This medium was used as the inoculation.

\section{Isolation of the Cultured Cells}

Following the termination of the needed time for culture, the culture medium was centrifuged at 4500 RPM and $4^{\circ} \mathrm{C}$ for $30 \mathrm{~min}$. Next, the supernatant was discarded, and the net weight of cells was recorded for each vial. The bacterial cells were stored at $-20^{\circ} \mathrm{C}$.

Cell Rupture by Lysozyme and Mild Ultrasonication The frozen bacteria ( $3 \mathrm{gr}$ ) were dissolved in buffer A (50 mM sodium phosphate buffer with $\mathrm{pH}: 7$ containing $0.3 \mathrm{mM}$ sucrose, $0.3 \mathrm{mM}$ EDTA, and $7 \%$ glycerol) followed by adding lysozyme $(100 \mu \mathrm{g} / \mathrm{mL})$. The suspension was shaken gently for $30 \mathrm{~min}$ at $4^{\circ} \mathrm{C}$ and was gently sonicated on ice $(20 \mathrm{KH})$ for $30 \mathrm{sec}$.

\section{Separation of Enzyme from Membrane using Triton $\mathrm{x}-100$}

Triton X-100 0.1\% (v/v) was added to the suspension obtained in the previous step. It was shaken gently for $2 \mathrm{~h}$ at $4^{\circ} \mathrm{C}$. After breaking the cells, the suspension was centrifuged at $10000 \mathrm{RPM}$, and $4^{\circ} \mathrm{C}$ for $1 \mathrm{~h}$. The enzyme activity and protein content were investigated in the supernatant, and Gram staining was performed on the precipitate to observe the remainder of unbroken cells. 


\section{Sodium Dodecyl Sulfate (SDS)-PAGE Electrophoresis}

Hydrolyzed starch gel $0.08 \%$ was copolymerized in SDS polyacrylamide $10 \%$ gel. A vertical mini system PROTEAN 3 with a thickness of $1 \mathrm{~mm}$ was used. For electrophoresis, $75 \mu \mathrm{L}$ of the upper solution was mixed with $25 \mu \mathrm{L}$ of Tris buffer $(\mathrm{pH}: 7)$ and incubated at $4{ }^{\circ} \mathrm{C}$ overnight. The buffer was composed of $2 \%$ SDS, 2-mercaptoethanol, 25\% glycerol, and $0.1 \%$ bromophenol blue. When SDS-PAGE was completed, the gel was cut into two parts, one of which was fixed with trichloroacetic acid $12.5 \%$ and stained with Coomassie blue R-25. The other part was immersed and moved twice in isopropranolol $25 \%$ and $10 \mathrm{mmol}$ buffer phosphate (pH: 7) for 10 min to remove SDS. Finally, it was put in $100 \mathrm{mmol}$ buffer phosphate $(\mathrm{pH}$ : 7) for $10 \mathrm{~min}$.

For staining, the gel was soaked in substrate solution (100 mg penicillin $\mathrm{G}$ in $50 \mathrm{~mL}+100 \mathrm{mmol}$ buffer phosphate with $\mathrm{pH}: 7$ ) and was located in a shaker for $25 \mathrm{~min}$. After washing, enzyme activity was assessed using $0.6 \% \mathrm{KI}$ solution and $6 \% \mathrm{I}_{2}$. The clear region representing penicillinase activity bands was highlighted in a purple background. Afterward, the gel was washed with acetic acid $5 \%$ for discoloration.

\section{Optimization of Production Steps}

Each time, a loop full of bacteria grown on a basic nutrient agar medium was collected and transferred to culture media. Several factors related to enzyme production were evaluated on this culture medium, including optimum $\mathrm{pH}$, optimum temperature, optimum time, and optimum RPM.

\section{Optimum pH for Penicillinase Enzyme Activity}

The active sites of enzymes often consist of ionizable groups. For maintaining the form of the active site, these groups should be in suitable ion form. In addition, the substrates might have ionizable groups, and only one ionic form can bind the enzyme. Therefore, environmental $\mathrm{pH}$ affects the enzymatic reaction rate. Most enzymes have the maximum activity in a specific $\mathrm{pH}$. The activity of these enzymes reduces in higher or lower $\mathrm{pH}$. The $\mathrm{pH}$ in which an enzyme represents the maximum activity is known as optimum $\mathrm{pH}$ (15). To find the optimum $\mathrm{pH}$, the reaction was repeated many times under diverse conditions (time, temperature, RPM).

\section{Impact of Temperature on Enzyme Activity}

In order to investigate the stability of the penicillinase enzyme against temperature, enzyme activity was assessed after $1 \mathrm{~h}$ at the temperatures of $20^{\circ} \mathrm{C}-45^{\circ} \mathrm{C}$ and $10 \mathrm{~min}$ at temperatures above $50^{\circ} \mathrm{C}$ at $\mathrm{pH}$ : 6.5 and 200 RPM. A specified amount of enzyme was poured in Eppendorf tubes sealed with Parafilm and was incubated for diverse times at different temperatures. The specimens were instantly cooled, and enzymatic activity was measured at $30^{\circ} \mathrm{C}$.

\section{Optimum Enzyme Production Time}

Finding the shortest time for producing the highest possible enzyme amount was the last step of optimization. The activity of the produced enzyme was assessed at different times.

\section{Optimum RPM}

Furthermore, optimizing the intensity of aerification is another factor evaluated for optimizing the culture medium. In the assessment of enzyme production rate in diverse shaker rounds, the highest rate was obtained. More aerification led to the inhibitory effect of oxygen and the diminished activity of the produced enzyme. The test was repeated several times, and enzyme activity was measured each time.

\section{Enzyme Activity Measurement}

The measurement of enzyme activity was carried out by spectrophotometer (CECIL CE9500), and the materials were added to a $1 \mathrm{~mL}$ cuvette according to Table 1.

Immediately after adding the sample, changes in the absorption of benzylpenicillin at $240 \mathrm{~nm}$ were recorded for $240 \mathrm{sec}$. Enzyme activity $\left(\frac{\Delta \mathrm{OD} 240}{\mathrm{~min}}\right)$ was calculated based on the linear part of the curve, and the unit number of enzyme activity was calculated per $\mathrm{mL}$ of the sample using the following formula. The value of 0.5 at $240 \mathrm{~nm}$ is the extinction coefficient of benzylpenicillin.

$$
\operatorname{Activity}(\mathrm{u} / \mathrm{ml})=\frac{\Delta \mathrm{OD} 240 / \mathrm{min}}{\text { sample } / \mathrm{mL} \times 0.5}
$$

Table 1. Requirements for measuring enzymatic activity

\begin{tabular}{lcc}
\multicolumn{1}{c}{ Solutions } & Test $(\mu \mathrm{L})$ & Blank $(\mu \mathrm{L})$ \\
\hline Distilled water $\left(\mathrm{dH}_{\mathbf{2}} \mathrm{O}\right)$ & 840 & 890 \\
\hline Buffer $(\mathbf{5 0} \mathrm{mM}$ sodium phosphate buffer, $\mathrm{pH}=\mathbf{6 . 5})$ & 100 & 100 \\
\hline Substrate (0.5 mM benzylpenicillin substrate)* & 50 & - \\
\hline Sample & 10 & 10 \\
\hline
\end{tabular}

*3.74 $\mathrm{mg}$ is dissolved in $1 \mathrm{ml}$ sterile $\mathrm{dH}_{2} \mathrm{O}$. The value of $50 \mu \mathrm{l}$ in the final volume of $1 \mathrm{ml}$ is equal to $0.5 \mathrm{mM}$. 


\section{Results}

About $8 \mathrm{gr}$ of cells was obtained in each one liter of culture. During the optimization procedure, culture was simultaneously prepared from bacteria to reach highly accurate results. This culture was inoculated in various media. Each time, one loop of bacterial colonies was taken from the bacteria grown on a basic nutrient agar medium and was transferred to the produced culture media. Several factors were assessed on these media, including optimum $\mathrm{pH}$, temperature, time, and RPM for enzyme production. The findings are shown in Figures 1-4.

Also. according to Figure 1, the highest penicillinase activity was found in $\mathrm{pH}$ : 6.5 with sodium phosphate buffer $50 \mathrm{mmol}$ as the optimum $\mathrm{pH}$ for enzymatic activity.

Moreover, the highest enzyme production rate was at $30^{\circ} \mathrm{C}, 200 \mathrm{RPM}$, and pH: 6.5 (Figure 2).

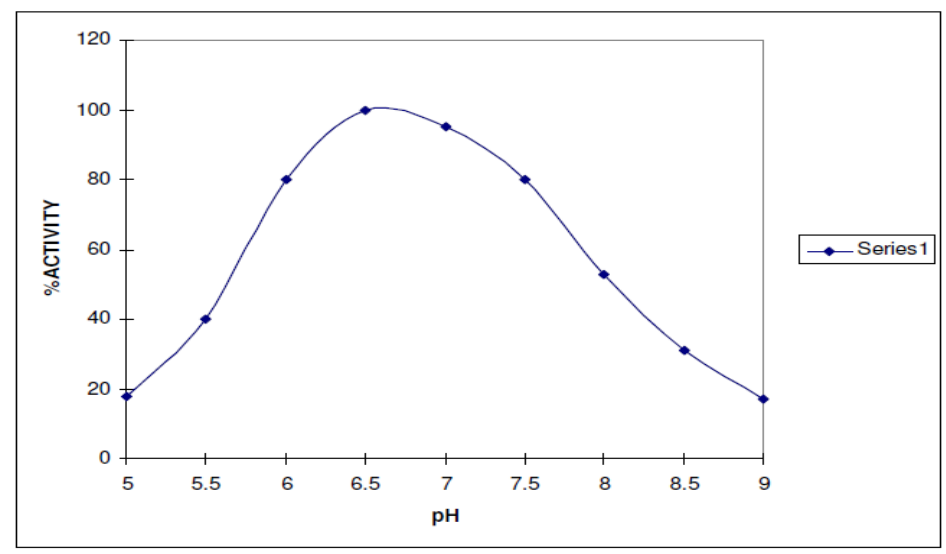

Figure 1. Effect of initial environmental $\mathrm{pH}$ on the rate of penicillinase production for obtaining the optimum $\mathrm{pH}$ of three distinct buffers, including 1) phosphate $50 \mathrm{mmol}, \mathrm{pH}=6.5-8,2$ ) buffer Tris hydrochloride $50 \mathrm{mmol}, \mathrm{pH}=8.5-10$, and 3) buffer acetate 50 $\mathrm{mmol}, \mathrm{pH}=4-6$. Figure 1 shows that the highest activity was found in $\mathrm{pH}=6.5$ with sodium phosphate buffer $50 \mathrm{mmol}$.

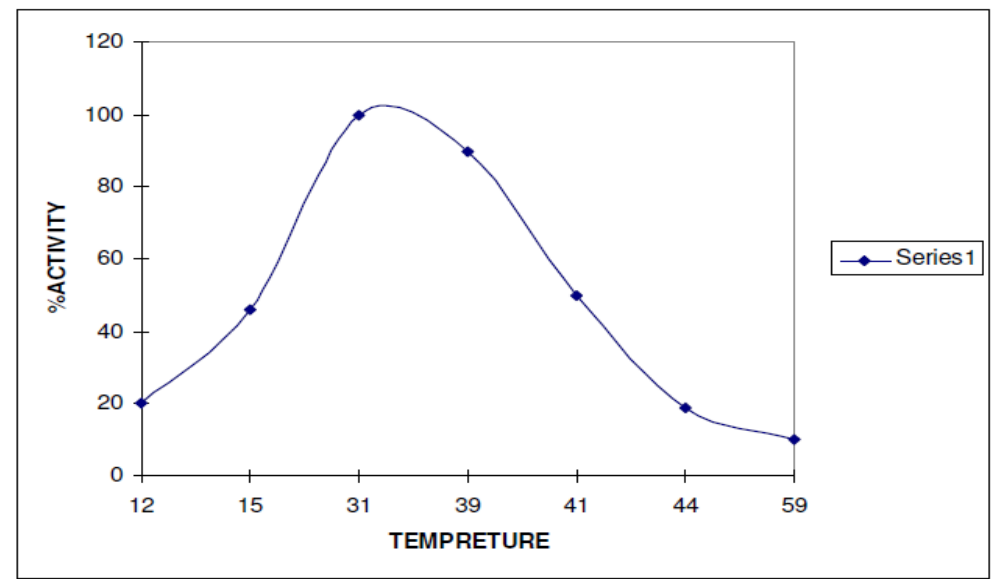

Figure 2. Impact of temperature on penicillinase production rate. This figure shows enzyme activity in different temperatures to $45^{\circ} \mathrm{C}$ for $1 \mathrm{~h}$ and over $45^{\circ} \mathrm{C}$ for $10 \mathrm{~min}$. According to this figure, temperature rise to over $45^{\circ} \mathrm{C}$ reduces enzyme stability as enzyme incubation at $60^{\circ} \mathrm{C}$ for 10 min drastically decreases enzyme activity.

Furthermore, optimizing the intensity of aerification is another factor evaluated for culture medium optimization. The influence of aerification is demonstrated in Figure 3 . In assessing enzyme production rate in diverse shaker rounds, the highest rate was obtained in $250 \mathrm{~mL}$ Erlenmeyer flasks in a 50
$\mathrm{mL}$ culture medium and 200 RPM. The enzyme production rate in these conditions reached 2394 units $/ \mathrm{mL}$. More aerification led to the inhibitory effect of oxygen and diminished the activity of the produced enzyme. 


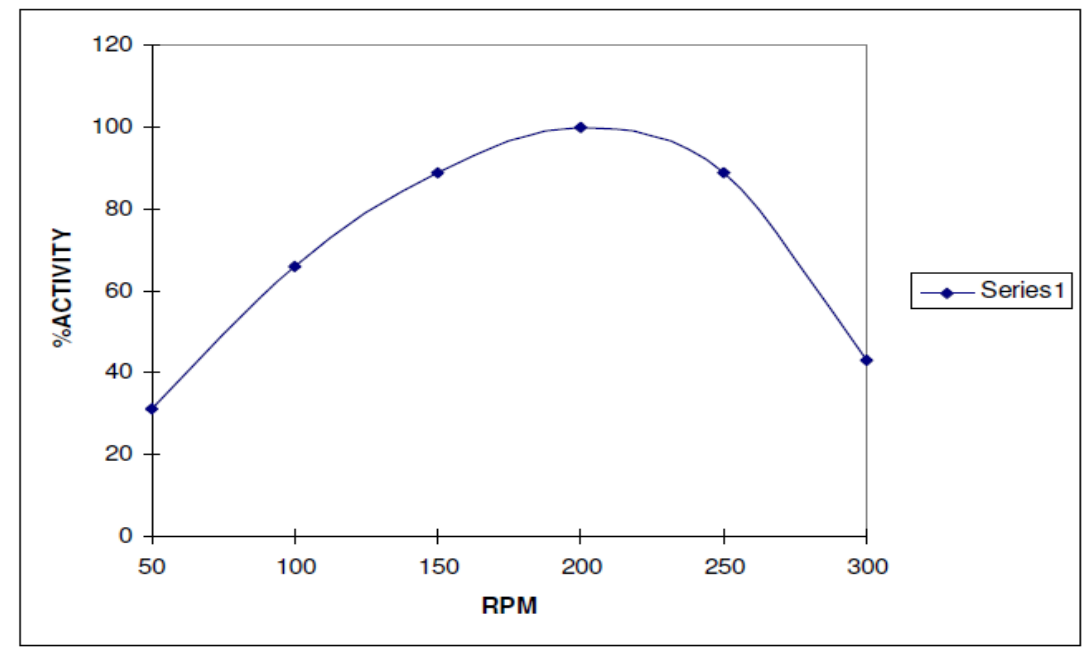

Figure 3. In assessing enzyme production rate in diverse shaker rounds, the highest rate was obtained in $250 \mathrm{~mL}$ Erlenmeyer flasks in a $50 \mathrm{~mL}$ culture medium and $200 \mathrm{RPM}$.

The results of optimizing enzyme production time are indicated in Figure 4. As could be seen, the best time for the isolation and extraction of the enzyme was $9 \mathrm{~h}$ after inoculation into the culture medium.
Following $9 \mathrm{~h}$, less enzyme was obtained. One of the possible reasons for reduced enzyme activity in a long time might be the presence of proteases produced by bacteria.

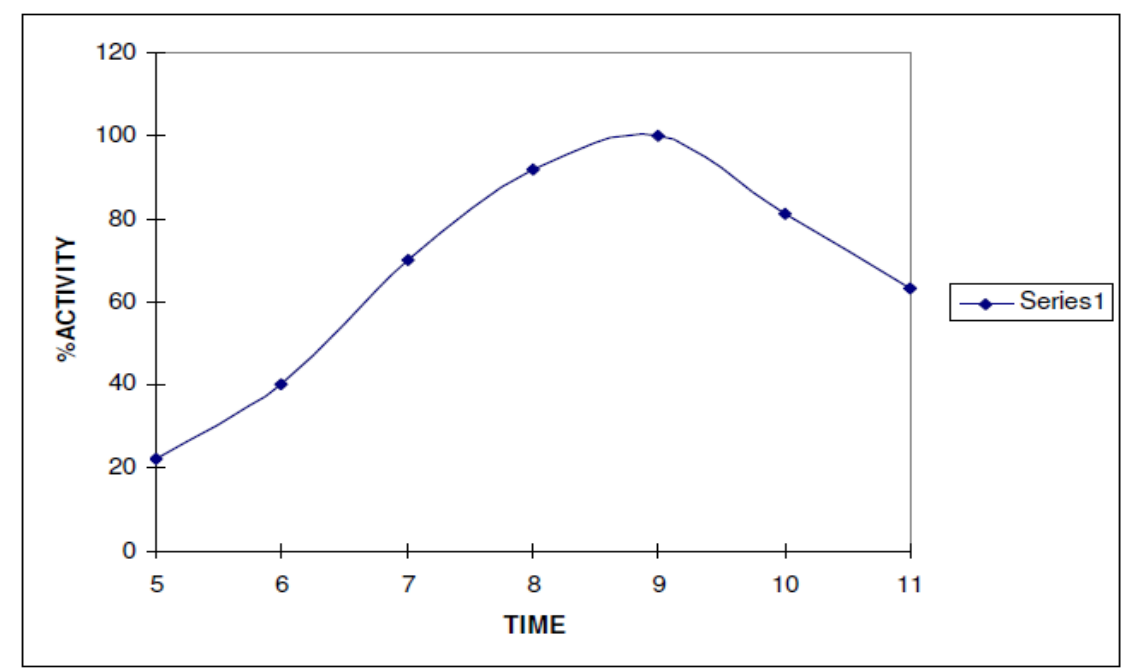

Figure 4. As could be seen, the best time for the isolation and extraction of the enzyme was $9 \mathrm{~h}$ after inoculation into the culture medium; after $9 \mathrm{~h}$, less enzyme is obtained.

\section{Discussion}

B. licheniformis bacterium is an appropriate microorganism for the extraction of penicillinase. Bacillus species have been shown to have the highest penicillinase activity. The enzyme produced by this species is better than the penicillinase of other bacteria in terms of specific activity and physicochemical properties. The suitable time for penicillinase production by the bacteria of other species was reported as 20,30, 48, and $96 \mathrm{~h}$. Moreover, the highest enzyme production rate for a 1 L culture was obtained by a 2 L Erlenmeyer and 200 RPM. Investigations demonstrated that the enzyme is generated in the logarithmic phase of cell growth and is more stable in the static phase. Usually, 8-12 $\mathrm{h}$ of growth is sufficient for enzyme production, which reaches the maximum in this time (12). Harvesting time was $9 \mathrm{~h}$ after the initiation of growth. At this time, the enzyme production rate was obtained in the optimum culture medium and conditions.

The other points include the $\mathrm{pH}$ values for cellular growth and enzyme production. The typical graph of penicillinase enzyme activity $\mathrm{pH}$ with benzylpenicillin substrate in Gram-positive bacteria shows the optimum $\mathrm{pH}$ as $6-7$, being accompanied by a rapid 
decrease in enzyme activity in $\mathrm{pH}$ over 9 and under 2.5. For Gram-negative bacteria, optimum activity is in the range of 5-8.5 (13). Neutral pH is essential for the optimum performance of units in the active site (16, 17). Penicillinase enzyme in $\mathrm{pH}: 4$ had the highest stability in 0.05 molar phosphate buffer. Enzyme activity was better in $\mathrm{pH}$ : 6-7 and the presence of glycerol (14). In the present study, $\mathrm{pH}$ : 6.5 was obtained as the optimum $\mathrm{pH}$ for enzyme production.

The penicillinase of $B$. licheniformis has been produced both as extracellular and membraneattached in diverse ratios. These two forms of the enzyme have distinct physicochemical properties (5, 12, 18). Therefore, total enzyme activity was measured after bacterial culture and the enzyme production in the supernatant following the centrifugation of a $9 \mathrm{~h}$ culture and in the cytoplasmic membrane after cell lysis. Another notable factor in the generation of the enzyme by $B$. licheniformis and other bacteria is environmental temperature. Although the optimum temperature for the growth of bacteria is $37^{\circ} \mathrm{C}$, investigations showed that penicillinase is a temperature-dependent enzyme, the production of which occurs at $28^{\circ} \mathrm{C}-35^{\circ} \mathrm{C}$ (3). In the current study, the highest rate of enzyme production was at $30^{\circ} \mathrm{C}$. At temperatures above $37^{\circ} \mathrm{C}$, cell growth augmented, while enzyme production declined.

Furthermore, the amount of oxygen dissolved in the culture medium affects penicillinase production. The solubility of oxygen is highly limited. Consequently, an optimum oxygen level should be determined and provided for each isolate. It has been indicated that enzyme production stops in high oxygen concentrations. Aerification could be obtained based on shaker settings and the relation of container space to the culture medium. As a result, oxygen solubility in the culture medium is improved due to the contact of the medium with air (6). The culture medium contained nitrogen sources (e.g., casein hydrolysate and peptone), carbohydrate sources (e.g., maltose and glucose), diverse concentrations of ions (e.g., magnesium sulfate) at an optimum concentration of $1 \%-2 \%$, and organic factors (e.g., phosphates) (12). Several reports show the inhibitory effect of polyalcohols and polysaccharides, such as lactose and fructose, on enzyme production (3). In the case of using glucose, $\mathrm{pH}$ decline might be prevented by $\mathrm{NaOH}$.

Maltose enhanced enzyme production four times at the concentration of $1 \%$. Phosphates are normally applied for culture medium preparation as the only non-organic factor that causes buffer properties in a medium in the physiological $\mathrm{pH}$ range while not being toxic for microorganisms. In addition, phosphates are considered as a phosphorous source required for bacterial growth (19). We used the concentrations of $0.08 \%$ and $0.06 \%$ of phosphate dipotassium.

Cell breakdown is a sensitive step in the purification procedure. Inaccuracy in this stage destroys proteins, especially those with biological activity, including enzymes. Various methods are utilized for cell breakdown considering the type of organism. The membrane of Gram-negative bacteria is highly stable, and more intense techniques, such as ultrasound, are needed, while the cell wall of Gram-positive bacteria easily breaks by distinct factors, including osmotic pressure and lysozyme due to the lack of outer membrane. Gram-positive bacteria lack an extracellular wall but possess a cytoplasmic membrane, a peptidoglycan layer, and a teichoic acid layer (1). Amphiphilic penicillinase is located and synthesized in the cytoplasmic membrane. In order to isolate membrane penicillinase, peptidoglycan and teichoic acid layers should be broken.

A considerable number of researchers have used a variety of releasing methods, such as repeated thaw and freeze, detergent, lysozyme, sonication, and trypsin. However, the conducted studies demonstrated that the thaw and freeze, as well as strong sonication techniques, are accompanied by a decrease in enzyme activity. On the other hand, the lysozyme enzyme alone releases less enzyme. Applying lysozyme followed by trypsin had a relatively better outcome but enzyme release was not complete. Using detergents alone led to the release of less enzyme $(6,12)$. In the present study, $100 \mathrm{mg} / \mathrm{mL}$ lysozyme followed by mild sonication for $30 \mathrm{sec}$ were applied to destruct the membrane. Afterward, Triton 100X was utilized to release the remaining penicillinase enzyme, which led to enhanced results compared to the methods applied in other investigations. Triton $100 \mathrm{X}$ plays a role in both releasing the remaining enzyme and enzyme stability $(13,14)$. After the complete breakdown of cells, the suspension was centrifuged at $10000 \mathrm{RPM}$ and $4^{\circ} \mathrm{C}$ for $1 \mathrm{~h}$. These observations were consistent with a report by Simons in 1978 (12).

Furthermore, for cell extract preparation, a suitable buffer is in a range where the intended protein has the highest stability with salt concentrations of 50-100 mmol. These buffers contain compounds, such as EDTA that free divalent metal ions and are used at concentrations $1-10 \mathrm{mmol}$ (20). On the other hand, when cell components are deconstructed, the hydrolytic balance of enzymes is disturbed, leading to mixing with other cellular components. Proteolytic enzymes are released in almost all cell extracts and should be inactivated because of their destructive impact on proteins and other enzymes 
Two methods can effectively reduce the activity of proteases, one of which is acting at temperatures below $4^{\circ} \mathrm{C}$ and the other one is using lysozymestabilizing compounds, such as sucrose and maltose. Lysosomes are the main source of proteases. Therefore, the destruction of these organelles results in the acidification of the solution and the release of proteases. Adding sucrose to the extraction buffer stabilizes the membrane of lysosomes. A buffer of choice for extraction should have sufficient buffer capacity for decreasing the acidification. In addition, some compounds, such as glycerol, are regarded as a protective and stabilizing factor for maintaining proteins in cold conditions with a proper concentration of $0 \%-20 \%(20)$.

Concentrated solutions of the pure enzyme are more stable than diluted solutions. The enzyme in cell extract is highly more stable and maintains activity even for minutes at boiling temperature. This could be attributed to the protective role of compounds with high molecular weight in the extract. Gelatin also has a $1 \%$ protective impact (21). The stability of penicillinase varies in distinct microorganisms. The enzyme in Neisseria gonorrhoeae loses $50 \%$ of its activity at $4^{\circ} \mathrm{C}$ after 5 days, becomes inactivated after 25 days at $25^{\circ} \mathrm{C}$, and is inactivated after $1 \mathrm{~min}$ at $60^{\circ} \mathrm{C}$ (22). Penicillinase produced by Haemophilus ducreyi is inactivated at $49^{\circ} \mathrm{C}$ after $20 \mathrm{~min}$ (20). The penicillinase

\section{References}

1. Stratton CW. The role of $\beta$-lactamases. Antimicrobics and Infectious Diseases. Newsletter 1996; 15(3): 17-28. [DOI:10.1016/1069-417X(96)83895-7]

2. Bush KA. Characterization of beta-lactamases. Antimicrob Agent Chemother. 1989;33(3):25963. [DOI:10.1128/AAC.33.3.259] [PMID] [PMCID]

3. Citri N. Penicillinase and Other $\beta$-Lactamases. The enzyme. 1971; 4(3):23-46. [DOI:10.1016/S1874-6047(08)60362-5]

4. Joshi UM, Shah HP, Sunk olli G.M. Penicillinase as amarker in enzyme-linked immuosorbent assay for a steroid hormone.Steroid. Biochem. 1978;19(1):419-421. [DOI:10.1016/00224731(83)90197-8]

5. Livermore DM. Lactamases in Laboratory and Clinical Resistance. Clin Micribiol Rev. 1995; 8(4):557-584. [DOl:10.1128/CMR.8.4.557] [PMID] of Escherichia coli is completely inactivated at $60^{\circ} \mathrm{C}$ in 5 min (24). Bacillus penicillinase is a highly stable enzyme and could be stored at room temperature without being denatured. Furthermore, it could be stored at $-15^{\circ} \mathrm{C}$ for several years without losing its activity. The activity of Bacillus penicillinase diminishes in temperatures over $60^{\circ} \mathrm{C}$ as it is active at $70^{\circ} \mathrm{C}$ only for $1 \mathrm{~min}(25)$.

\section{Conclusion}

We used $B$. licheniformis as it reaches maximum growth in a shorter time and has the highest enzyme production rate with increased activity during this time. In this study, $8 \mathrm{gr}$ cells in each one liter of culture were obtained. Also, the maximum and optimum enzymatic activity were shown in $\mathrm{pH}=6.5$, temperatures $45^{\circ} \mathrm{C}$, and the 200 RPM of the medium culture. In addition, $9 \mathrm{~h}$ after inoculation was the best time for the enzyme extraction.

\section{Acknowledgment}

None.

\section{Funding}

None.

\section{Conflict of Interest}

There is no conflict of interest between the authors.

6. Pollock MR. The measurement of the liberation of penicillinase from Bacillus subtilis. J Gen Microbiol. 1961;26(2):239-253. [DOI:10.1099/00221287-26-2-239] [PMID]

7. Pollock MR. The mechanism of liberation of penicillinase from Bacillus subtilis. J Gen Microbiol. 1961;26(2):267-276. [DOI:10.1099/00221287-26-2-267] [PMID]

8. Pollock MR. The differential effect of actinomycin D on the biosynthesis of enzymesin Bacillus subtilis and Bacillus cereus. Biochim. Biophys Acta. 1963; 76(3):80-93. [DOI:10.1016/0926-6550(63)90009-4]

9. Priest FG. Extracellular enzyme synthesis in the genus Bacillus. Bacteriol Rev. 1977; 41(3): 711753. [PMID] [PMCID]

10. Pollock MR. Purification and properties of penicillinases from two strains of Bacillus licheniformis: a chemical, physicochemical, and physiological comparison. Biochem. 1965; 


\section{4(3):666- 675. [DOI:10.1042/bj0940666] [PMID] [PMCID]}

11. Smit PW, Tal PC, Davis B D. Bacillus licheniformis penicilhinase: cleavage and attachment of lipid during cotranslational secretion. Proc. Natl Acad Sci. 1981; 78(6):3501-3505.

[DOI:10.1073/pnas.78.6.3501] [PMID] [PMCID]

12. Simons K, Sarvas M, Garoff $H$, Helenius A. Membran-band and secreted Forms of Penicillinase from Bacillus Licheniformis". J Mol Biol. 1978; 12(6); 673-690. [DOI:10.1016/00222836(78)90015-3]

13. Yamamoto S, Lampen JO. Membrane Penicillinase of Bacillus Licheniformis a Phospholipoprotein. J. Biol. Chem. 1974; 250(8): 3212-3213. [DOl:10.1016/S00219258(19)41613-X]

14. Yamamoto S, Lampen O. The Hydrophobic Membrane Penicillinase of Bacillus Licheniformis 749/ C.J. Bacteriol Chem. 1976; 251(13): 4102- 4110. [DOl:10.1016/S00219258(17)33361-6]

15. Wiseman A. Handbook of enzyme. Biotechnology. 1985; 2 Ed. [DOI:10.1016/S00032670(00)86504-6]

16. Moews PC, et al. " Beta-Lactamases of Bacillus Licheniformis 749/C at 2A Resolution". Protein. Structure Functional and Genetics. 1990; 7(2): 156-171. [DOI:10.2210/pdb2b/m/pdb] [PMID]

17. Lamotte-Brosseur J. Pka calculations for Class A beta-Lactamases: Influence of substrate binding
Pka Sci. 1999; 8(2):404-409.

[DOI:10.1110/ps.8.2.404] [PMID] [PMCID]

18. Thatcher DR. Lactamases (Bacillus Licheniformis). Methids Enzymol. 1975; 43:653664. [DOI:10.1016/0076-6879(75)43130-5]

19. Davies JW, Collins JF. The induction of Bacillus Licheniformis Penicillinase by Vanadat, Moybdate and Tungstate anions. Biochim Biophys Acta. 1970; 217(2):552-554. [DOI:10.1016/0005-2787(70)90557-5]

20. Elv $H$, Angel $S$. Protein purification Methods.John Wiley (U. S. A) New York. 1989; 1th ed:47-97.

21. Abraham EP. Penicillinase. Methods. Enzymology J. 1952; 2: 120-124. [DOI:10.1016/S0076-6879(55)02177-0]

22. Castillo MC, Islas MI, Nader OM.Purification and Characterization of B -Lactamases from Nisseria gonorrhoeae from Clinical Samples. Microbiologia. 2001; 43(2):70-75.

23. Lawung R. purification and characterization of $B$ -Lactamases from Haemophilus ducreyi in $E$. coli. Protein Expr Purif. 2001; 23(1):151-158. [DOI:10.1006/prep.2001.1485] [PMID]

24. Ben-Mahrez. Purification and Biochemical properties of beta- Lactamases from E. coli. J Toxicol Toxin Rev. 1999; 18(3):221-228. [DOI:10.3109/15569549909162643]

25. Matangne $A$. The diversity of the Catalytic properties of class A -Lactamases. Biochem J. 1990; 265(1): 131-146. [PMID] [PMCID] [DOI:10.1042/bj2650131] 